\title{
Family firms in the global economy: toward a deeper understanding of internationalisation determinants, processes and outcomes
}

Article

Accepted Version

De Massis, A., Frattini, F., Majocchi, A. and Piscitello, L. (2018) Family firms in the global economy: toward a deeper understanding of internationalisation determinants, processes and outcomes. Global Strategy Journal, 8 (1). pp. 3-21. ISSN 2042-5805 doi: https://doi.org/10.1002/gsj.1199 Available at https://centaur.reading.ac.uk/84140/

It is advisable to refer to the publisher's version if you intend to cite from the work. See Guidance on citing.

To link to this article DOI: http://dx.doi.org/10.1002/gsj.1199

Publisher: Wiley for the Strategic Management Society

All outputs in CentAUR are protected by Intellectual Property Rights law, including copyright law. Copyright and IPR is retained by the creators or other copyright holders. Terms and conditions for use of this material are defined in the End User Agreement. 


\section{CentAUR}

Central Archive at the University of Reading

Reading's research outputs online 


\title{
FAMILY FIRMS IN THE GLOBAL ECONOMY: TOWARD A DEEPER UNDERSTANDING OF INTERNATIONALIZATION DETERMINANTS, PROCESSES, AND OUTCOMES
}

\begin{abstract}
Research on the internationalization of family firms has flourished in recent years, yet the mechanisms through which family involvement shapes the determinants, processes, and outcomes of internationalization remain little understood and largely undertheorized. We contribute to research at the intersection of international business and family business by examining the roles of different sources of family firm heterogeneity and the context in shaping the determinants, processes, and outcomes of business internationalization. Drawing on this analysis, we summarize the articles published in this special issue and set out an agenda for further research aimed at advancing a more fine-grained and contextualized understanding of internationalization in family firms.
\end{abstract}

Keywords: family business; family firms; internationalization; globalization; international diversification.

\section{INTRODUCTION}

Family businesses dominate the economic landscape. According to the latest statistics from the Family Firm Institute, family firms account for two thirds of all businesses around the world, generate around 70-90 percent of annual global GDP, and create 50-80 percent of jobs in the majority of countries worldwide (Family Firm Institute, 2017). In the United States, one third of S\&P 500 firms are owned/controlled and/or managed by the founding family, family firms account for 89 percent of total tax returns, 64 percent of GDP, and employ 62 percent of the total workforce (Anderson and Reeb, 2003; Astrachan and Shanker, 2003). 
While the importance of family firms is even greater in Europe (Botero et al., 2015), they also significantly contribute to the growth of economies in South and East Asia, Latin America, and Africa (Tharawat Magazine, 2014).

Globalization, aggressive worldwide competition, technological developments, and new growth prospects beyond national borders increasingly force family firms toward international diversification and global strategic growth to nurture their competitive advantage and/or to overcome economic downturns. Internationalization allows these firms to take advantage of economies of scale, lower labor costs and commodity prices, access to qualified and cheaper human resources and know-how in foreign industry clusters, and local opportunities for innovation. Internationalization is widely acknowledged as an important determinant of the sustained performance of family firms in the global economy. Irrespective of size, these firms have recently seen significant international growth through exports, foreign direct investments, contractual agreements, joint ventures, or a mix of these entry modes in foreign markets. In fact, many of the world's largest multinational companies (MNCs) are family influenced (Casillas and Pastor, 2015), and several small- and mediumsized family enterprises are internationally recognized for their globalization strategies (e.g., for recent analysis on German Mittelstand firms, see De Massis et al., 2018).

Therefore, the interest of management and organization studies in family firm internationalization does not come as a surprise. Notwithstanding that the worldwide diffusion and international growth of family businesses has intrigued researchers for decades, the debate on the role of family involvement in influencing international diversification, growth, and performance is still far from conclusive.

The first studies on this topic were published in the late 80 s and early 90 s. As the number of studies has exponentially grown in the last decade, the need to systematize them has recently prompted a number of reviews and meta-analyses (Kontinen and Ojala, 2010; Pukall 
and Calabrò, 2014; Arregle et al., 2017). Figure 1 reports the results of a search using the Web of Science and Scopus databases ${ }^{1}$. The trend is similar when using Google Scholar, with only four studies in the $80 \mathrm{~s}, 11$ in the $90 \mathrm{~s}, 110$ in the $2000-2010$ period, and 234 in the 20112017 period.

\section{Insert Figure 1 here}

The main question these studies address is whether family firms internationalize less or more than non-family firms generally in terms of foreign sales, exports, and - more recently - foreign direct investments. Research thus far essentially agrees that specific aspects distinguishing firms with family involvement from other forms of business organizations such as the innate tendency of family owners to centralize and personalize administrative power (Carney, 2005), their personal investment and consequent parsimony (Carney, 2005), the pursuit of non-economic goals (Kotlar and De Massis, 2013; De Massis et al., 2018), and the asymmetrical treatment of family and non-family employees (Verbeke and Kano, 2012) pose unique challenges for their growth and development. However, the same consensus does not exist in relation to the effect that the distinctive features of family firms have on the extent and form of internationalization.

On the one hand, family firms are considered inclined to remain in their domestic markets and adopt conservative behaviors, tending to protect their socioemotional wealth (GomezMejia et al., 2007; Kotlar et al., 2017), which refers to the family members' affective endowment, including family control and influence over the firm, their emotional attachment

\footnotetext{
${ }^{1}$ We searched these databases using the following keywords: 'family ownership' 'family firm' 'family-owned business enterprise' 'family coalition' 'family involvement' 'families' 'family business' 'family control ' 'founder' 'founding family' 'lone founder' 'family business group', in combination with 'internationalization' 'internationalisation' 'entry process' 'entry' 'international operations' 'international trade' 'globalization' 'globalisation' 'international' 'global' 'mode of entry' 'foreign' 'export' 'international sales' 'international commitments' 'multinational' 'foreign direct investment' 'global strategy', and ensured the substantial relevance of the findings combining the keywords with the paper titles.
} 
and shared identification with the firm, their social ties with stakeholders, and their desire to renew family bonds through dynastic succession. This view is consistent with the common assumption that family firms have a strong connection to their home regions and local roots (Bird and Wennberg, 2014). Moreover, family owners are likely to have a larger share of their capital bound to the firm (Casson, 1999), which often leads to their aversion to risky investments in international markets.

Consequently, the majority of studies argue that family firms internationalize less (Fernàndez and Nieto, 2005, 2006). This is likely due to their well-known reluctance to dilute ownership, which may lead to the lack of not only financial resources needed to grow internationally (Anderson and Reeb, 2004), but also specialized management with specific knowledge of different consumer tastes, international distribution policies, production, and logistics (Graves and Thomas, 2006). Gómez-Mejía, Makri, and Larraza-Kintana (2010) support these conclusions arguing that family firms tend to be more conservative than nonfamily firms. Therefore, risk avoidance considerations push family firms toward a greater focus on the home market, and when they do internationalize, they tend to focus on countries that are geographically and culturally closer.

On the other hand, family firms have recently been recognized as important protagonists of international entrepreneurship. Their particular characteristics, the strength of family involvement and emotional attachment to the firm, e.g., firm-specific human capital (Gedajlovic and Carney, 2010), patient capital and long-term orientation (De Massis et al., 2018), lower agency costs (Chrisman, Chua and Litz, 2004; Miller and Le Breton-Miller, 2006), and higher endowment of social capital (Gallo and Pont, 1996; Piva, Rossi-Lamastra, and De Massis, 2013; Sirmon and Hitt, 2003; Zhara, 2003) act as incentives to embark on global initiatives. 
Other scholars, such as Arregle et al. (2017) in their recent meta-analysis comparing family and non-family firms, find no statistically significant difference in their degree of internationalization. Specifically, family involvement is almost non-influential (Carr and Batemann, 2009) at least in large firms, or the relationship with internationalization may even have an inverted U-shape (Sciascia et al., 2012) where for a low level of family ownership the positive relationship holds, while for higher level of ownership the curve slopes downwards.

Departing from these discussions, some authors (Verbeke and Kano, 2012; Hennart, Majocchi and Forlani, 2017) argue that the question of whether family firms internationalize more or less than their non-family counterparts is ill-posed, since every firm has an optimal level of internationalization, and the important theoretical problem to address is under which conditions family firms tend to move toward or away from these optimal levels.

In addition, scholars tend to use different theoretical perspectives to frame the relationship between family involvement and internationalization, which in turn promotes the use of different empirical methodologies, often leading to different conclusions.

This state-of-the-art clearly indicates that the relationship between family involvement and internationalization is quite complex, which requires accounting for the heterogeneity of family firms (e.g., Chua et al., 2012) and several contingency factors at the intersection of international business and family business, even suggesting assemblages of different theoretical perspectives (e.g., Reuber, 2016).

In this article, we contribute to research precisely at this intersection of international business and family business by examining the roles of different sources of family firm heterogeneity and the context in shaping the determinants, processes, and outcomes of family firm internationalization, and by outlining some promising directions for future theoretical 
and empirical research on the internationalization of family firms. Furthermore, we summarize the papers in this special issue that constitute cutting-edge studies on the topic.

\section{INTERNATIONALIZATION OF FAMILY FIRMS: THE KEY ROLE OF}

\section{HETEROGENEITY AND THE CONTEXT}

Once acknowledged that family firms differ from non-family firms, it becomes key to examine the heterogeneity among family firms both theoretically and empirically (e.g., Chua et al., 2012; Arregle et al., 2017). Not all family firms are the same and not all pursue similar internationalization strategies. Accordingly, some studies investigate different types of family firms, exploring the differing role of family and non-family managers in the business (Graves and Thomas, 2006; Muñoz-Bullon and Sanchez-Bueno, 2012; Sanchez-Bueno and Usero, 2014).

In this vein, Majocchi and Strange (2012) investigate the role of board composition and the specific contribution of external members on the board of listed family firms with respect to their international diversification. Fernández and Nieto $(2005,2006)$ study the effect of the presence of second or subsequent generations in the management team, finding a positive relationship with export propensity and intensity in a sample of Spanish firms in the19911999 period. Sciascia et al. (2012) analyze the combination of family and external capital, concluding that an optimal mix exists. Arriving at similar conclusions, Arregle et al. (2012) study the difference between family-owned and family-influenced firms, while D'Angelo et al. (2017) argue that to promote export performance, the hiring of external managers should be sustained and reinforced with a parallel action to attract external capital.

However, all these studies investigate the impact of family firm heterogeneity on one specific dimension of internationalization, i.e., foreign sales/exports, ignoring other relevant dimensions, such as foreign direct investments (FDIs). Although a number of studies recently 
studied FDIs in the context of family firms (Carney et al., 2017), the findings are still inconclusive. Investigating the Indian automotive and pharmaceutical sector, Bhaumik, Driffield, and Pal (2010) find that family firms are less likely to invest overseas, while Lien et al. (2005) analyze a sample of Taiwanese firms and argue the opposite. Based on diversification motives, they find that family firms are more likely to undertake FDIs. Overall, while all these studies find that family ownership affects FDI policies, few investigate the role of different family characteristics on FDI decisions. This leaves considerable room to investigate the role of family heterogeneity, and whether and how family ownership and control affect other relevant internationalization dimensions, such as choice of entry mode (Boellis et al., 2016; Chang, Kao, and Kuo, 2014; Kuo et al., 2012. Liang, Wang, and Cui, 2014; Pongelli, Caroli, and Cucculelli, 2016), and internationalization speed (Lin, 2012).

On a more general level, the inclusion of corporate governance variables in the theoretical framework is relatively new and would seem to be a promising direction for future research (Strange et al., 2009) challenging corporate governance literature. For example, agency theory makes clear predictions about performance, but produces mixed predictions about family firm internationalization. In its original version (Jensen and Meckling, 1976), agency theory posits that family ownership mitigates the potential conflicts between ownerprincipals and managerial agents, lowering agency costs (Denis, Denis, and Sarin, 1999). However, in family firms, type-II agency costs (Villalonga and Amit, 2009) are amplified due to potential conflicts between large family shareholders (blockholders) and minority nonfamily shareholders. In these circumstances, family owners may leverage their controlling position to extract private benefits at the expense of other minority shareholders (Cheng, 2014; Gedajlovic and Carney, 2010). In both cases, while the consequences on performance are relatively evident (Miller, Minichilli, and Corbetta, 2013), the effect of the distinctive 
agency issues of family firms on internationalization are far from clear. Classic familycentered stewardship theory offers a similarly ambiguous approach toward internationalization (Miller et al., 2007), emphasizing the strengths of family firms in terms of strong managerial identification with the firm, deep knowledge of the business, continuity and speed of command, social capital, and the strength of family brand names. However, these family assets may turn into limitations to international growth when requiring new knowledge, new managerial skills, and new capital (Bloom and Van Reenen, 2007; Claver, Rienda, and Quer, 2009).

Using a behavioral lens, the Socioemotional Wealth (SEW) approach identifies these same strengths and weaknesses of family involvement (Berrone, Cruz, and Gomez-Mejia, 2012), underlining the pivotal role of the utility that family owners derive from pursing familycentered non-economic goals. Based on risk avoidance considerations, Gomez Mejia et al. (2010) argue that family firms are pulled in two opposite directions: toward greater internationalization to dilute geographically concentrated business risks, but also toward a lower level of export to preserve the family's SEW, avoiding external funding and nonfamily executives (Berrone et al., 2012). Based on their empirical findings rather than on explicit theoretical arguments, the authors conclude that the latter direction will eventually prevail.

Since family firm behavior is affected by institutions and differs from country to country, another research stream investigates the role of the institutional setting and formal and informal country-specific institutions (Bhaumik et al., 2010; Carney et al., 2017). Arregle et al. (2017), for example, consider the moderating effects of the level of minority shareholder protection and trust toward people from other nations.

The different empirical findings and theoretical approaches call for reconciling these seemingly incompatible family firm and internationalization theories. Different authors have 
recently moved into this promising direction, for instance, suggesting the need for a more general framework able to integrate internationalization, corporate governance, and family firm theories (e.g., Aguilera and Crespi-Cladera, 2012), or using both agency and stewardship theories to justify the different international performances of firms with and without family leaders at high and low levels of regional focus (e.g., Banalieva and Eddleston, 2011), or integrating agency and stewardship theories into transaction cost economics (e.g., Gedajlovic and Carney, 2010; Verbeke and Kano, 2010, 2012; Majocchi et al., in press) to define family firms as a specific governance institution.

\section{Sources of heterogeneity in the internationalization of family firms}

Table 1 summarizes some important sources of heterogeneity that should be taken into account to understand the complexity of the determinants, processes, and outcomes of family firm internationalization: one the one hand, emphasizing the need to examine different sources of heterogeneity in family involvement, the behavioral propensities of the involved family, the strategic drivers of family firms, the internationalization processes and outcomes; on the other hand, emphasizing the need to examine the role of the context as a source of heterogeneous family firm internationalization behavior.

\section{Insert Table 1 here}

\section{Family involvement}

The contention that family involvement affects firm behavior and performance is not new (e.g., Zahra, 2003), although some scholars have cautioned that family involvement is a necessary but insufficient condition for family firms to behave in a distinctive way, meaning that such involvement is insufficient to directly determine distinctive family firm processes unless taking into account the behavioral propensities of the involved family, i.e., willingness 
and ability (De Massis et al., 2014; De Massis, Di Minin, and Frattini, 2015). More recently, some scholars (e.g., Chrisman et al., 2015) pointed to the importance of considering both the degree and type of family involvement to understand how family involvement translates into firm behavior. This entails capturing the heterogeneity of the family and its effects, an accomplishment that existing family business research has scarcely achieved (Combs et al., 2017; Jaskiewicz and Dyer, 2017).

Pioneering studies highlight the relevance of family structures (Aldrich and Cliff, 2003) and the family system (Olson et al., 2003) to understand family firm behavior and outcomes, and a recent study shows the implications of family functionality for family business innovativeness (Filser et al., 2017). However, we still lack a comprehensive overview linking the main family science theories and relevant dimensions of family heterogeneity to enable understanding the influence of family involvement (Jaskiewicz and Dyer, 2017), which may help us theorize how such involvement exercises its effect on family business behaviors and outcomes through a direct effect on the family's behavioral propensities.

Building on the work of Jaskiewicz and Dyer (2017), we identify four dimensions of family heterogeneity: family structures, family functions, family interactions, and family events.

Family structure refers to a group of individuals who share family ties, consider themselves part of a family, and interact with each other (e.g., Galvin, Bylund, and Brommel, 2012). Different families may be characterized by different structures (e.g., nuclear families vs. extended families vs. domestic partnerships vs. same-sex marriages vs. multiple marriages). Family structures may affect the managerial discretion of individuals, their capabilities through resource mobilizations, and their motivations; yet family business research implicitly assumes the prevalence of particular family structures, such as the nuclear family. 
Family functions relate to the functions families assign to their members and expect of them (Popenoe, 1996). Families can be responsible for different functions, such as ensuring that family members have employment and status, training and educating the young generation, elderly care, and old age security, spare time activities, etc. Understanding family functions is important because these influence the behavioral propensities of the involved families, for instance, by constraining access to the family resource pool or stimulating the family's intention to perpetuate control in the hands of the family. Yet, empirical evidence on the way these functions may affect family firm behaviors and outcomes is rather limited.

Family interactions refer to the type of interactions that characterize family member relationships. Three prominent family science theories have been mainly used to examine the heterogeneous interactions among family members: family communication patterns theory (Fitzpatrick and Ritchie, 1994; Ritchie and Fitzpatrick, 1990), parental control theory (Baumrind, 1971), and intergenerational solidarity theory (Silverstein and Bengtson, 1997). These respectively consider communication patterns in families, parenting styles, and level of intergenerational solidarity between parents and their adult children (e.g., family cohesion) as potential determinants of family firm behavior and outcomes (Jaskiewicz et al., 2017).

Although pioneering studies indicate that lively family interactions can have important effects on specific family firm behaviors, such as, for instance, entrepreneurship behavior (Danes et al., 2008), this dimension of family heterogeneity has been largely overlooked in family business literature.

Family events relate to those episodes in the family lifecycle that change the structure and functions of families and member interactions. Examples of family events are births, marriage, divorce, and remarriage. Such events typically determine shifts from one family lifecycle stage to another, which may have implications for family firm behaviors and outcomes. Although some family science theories, such as family development theory 
examining the common lifecycle stages of families (Mederer and Hill, 1983; Rodgers, 1964) implicitly point to the possible implications of family events on family firm behavior and outcomes, such implications have not yet been empirically accounted for in family business research.

In summary, family structures, family functions, family interactions, and family events are four dimensions of family heterogeneity that should be taken into account to better understand both the degree and type of family involvement, and its effect on the behavioral and strategic propensities of the involved family.

\section{Behavioral propensities of the involved family}

Drawing on the work of De Massis et al. (2014, 2015), we distinguish three behavioral propensities that affect the involved family's choice of strategic drivers to produce distinctive firm behavior: ability as discretion, ability as resources, and willingness.

Ability as discretion is defined as the involved family's discretion to direct, allocate, add to, or dispose of a firm's resources. This includes latitude in selecting the direction of the organization and in choosing from among the range of feasible strategic, structural, and tactical decisions (Hambrick and Finkelstein 1987; Morck, Shleifer, and Vishny, 1988).

Ability as capability refers to those capabilities that members of the involved family need or should use to lead the firm in the preferred direction.

Willingness is defined as the involved family's favorable disposition to engage in distinctive behavior. This has been attributed to transgenerational succession intentions, socioemotional wealth concerns, and commitment to the business (Chrisman et al. 2012; Gomez-Mejia et al., 2007). These three behavioral propensities affect the strategic drivers of family firms, which we examine next. 


\section{Strategic drivers of family firms}

Building on Chua et al. (2012), we identify three strategic drivers that family firms must leverage to produce distinctive behavior: governance systems, resources, and goals.

Governance systems consist of the incentives, monitoring, and authority structures, as well as the norms of accountability that shape the policies and strategies a firm uses to create longterm value for stakeholders (cf., Carney, 2005). The family exercising its ability as discretion to govern the firm may lead to the board of directors being entirely controlled by family members or ownership involving pyramids, cross-holdings, and dual voting class shares (Claessens, Djankov, and Lang 2000), allowing the family to bypass the board when making strategic decisions (Carney 2005; Lorsch and MacIver, 1989). Likewise, the presence of a family Chairman/CEO or institutional investors is another aspect of heterogeneity in the governance systems of family firms.

The resources of a family firm can be financial, social, human, and emotional (Habbershon and Williams, 1999), and how such resources are developed, deployed, and discarded depends largely on the involved family's ability as capability.

Goals in family firms can be economic vs. non-economic as well as family-centered vs. business-centered (Chrisman et al., 2012; Kotlar and De Massis, 2013) and are a major cause of heterogeneity of family firm behavior (Chua et al., 2012). The distinctive strategic goals of the family firm emerge as a result of the involved family's willingness and abilities. For instance, if the family is not willing to pursue family-centered goals, instead prioritizing business-centered goals, then clearly the family-centered goals will not be pursued. Likewise, families that lack the discretion and/or capabilities needed to lead the firm in the preferred family-centered direction will not be able to pursue such goals, for instance, when there are influential non-family shareholders or managers who object, and/or when the family lacks the resources needed. 


\section{Internationalization processes}

Internationalization processes can be simplified into four key aspects: (i) locality vs.globality; (ii) scope, modes, and location choices; (iii) timing and speed of internationalization; (iv) international business models.

The locality vs. globality trade-off refers to the extent to which a family firm chooses to be anchored to its local roots rather than pursue global growth and/or operate internationally. Family firms are often torn between their local roots and their desire and need for global growth and international activities (Graves and Thomas, 2008). For instance, the attachment of family firms to their home territory's tradition (De Massis et al., 2016a) may lead them to be inclined to focus on the local context rather than pursue internationalization (e.g., Bird and Wennberg, 2014). At the same time, other types of family firm goals, as well particular resources and governance configurations, such as the presence of internationally-oriented institutional investors, may influence their decision-making toward becoming internationally more active.

The internationalization scope, modes, and location choices are pivotal aspects of firm size and configuration. Scope refers to the firm's geographic extent (Lin, 2012), while mode defines the means of entry in foreign markets, and refers to the degree of control over foreign activities. Whether family firms tend to internationalize toward closer countries rather than pursue a global scope (e.g., Gomez-Mejia et al., 2010) and whether family members prefer keeping control within the family (as they are typically unwilling to dilute their stake in the firm) are still open questions.

How quickly firms become international after their foundation i.e., their speed of internationalization, is one of the more relevant aspects of the process (e.g., Casillas and Moreno-Menéndez, 2014). Once again, family involvement plays two opposing roles. On the 
one hand, family firms tend to be quicker in their decision processes, since family culture fosters a more homogenous management team that allows family firms to promptly react to changes in the environment typical of international markets (e.g., Kontinenand and Ojala, 2012). On the other hand, the desire to protect family wealth and pass the business to future generations makes family firms more risk averse and therefore slower to leap into new markets without adequate preparation (e.g., Gomez-Mejia et al., 2010).

International business models refer to the options in terms of the focused (niche) vs. mass market (broad) strategy that family firms adopt in foreign markets (e.g., Hennart, 2014). When firms with fewer resources - especially in the case of small and medium-sized family firms - focus their activity on a limited range of high quality products and services targeted at a worldwide audience of knowledgeable customers, they can achieve significant international results (Simon, 2009; Hennart et al., 2017). Conversely, mass markets strategies typically require significant investments in foreign production facilities, distribution and marketing policies, but also specialized managers with extensive international knowledge (e.g., De Massis et al., 2018). These strategies are typically followed by larger family firms and family MNCs, such as Samsung, Tata Consultancy Services, Toyota, and Walmart.

\section{Internationalization outcomes}

The family firm's internationalization outcomes and performance in terms of achieving both economic and non-economic goals will flow from the internationalization processes.

Such economic and non-economic outcomes and performance can vary when considering the firm, its subsidiaries, the business and family systems. Under- or over-performance compared to the aspiration level ensuing from the goals may then lead to revising the strategic drivers, behavioral propensities, or even family involvement through feedback-loop processes. 


\section{Context}

In an attempt to integrate the role of context in our framework, we focus on two broad categories of contexts (Banalieva, Eddleston, and Zellweger, 2014): first, the exo context, which refers to the economic, social, political, legal, cultural, spatial, and technological environment; second, the chrono context, which consists of the life courses of the family and business systems, and encompasses factors that lead to evolutionary or punctuated changes along the family's and the business's life, such as succession, business exit, mergers and acquisitions, declining performance, and environmental jolts. Both the exo and chrono contexts affect the determinants, processes, and outcomes of family firm internationalization.

\section{ARTICLES IN THE SPECIAL ISSUE}

The seven articles featured in this special issue draw on different theoretical perspectives and employ different methodologies. However, a number of common themes emerge: first, the focus on various dimensions of heterogeneity among family firms; and second, the role of the exo and chrono context.

Hernandez et al. (2018) compare family and non-family firms and study how institutional distance influences their international location choice. Specifically, they argue that family firms do not respond to institutional pressures in the same way as non-family firms. Through a quantitative analysis of Italian firms observed in the period 2000-2013, the authors show that firms are generally more likely to choose foreign locations with higher institutional quality, i.e., countries with clearer rules, more secure systems, and more transparent institutions. Moreover, compared to non-family firms, family firms are less reluctant to invest. In locations with institutional voids, where family firms' social capital facilitates access to and screening of new business opportunities (Carney, 2005), family firms may exploit their relational capabilities - those that enable them to better position themselves than 
non-family firms to benefit from the favors of politicians and other networks, thus confirming the role of the external (exo) context in influencing family firms' internationalization decisions.

Alessandri et al. (2018) consider both the distinction between family firms and non-family firms, and the heterogeneity among family firms. Specifically, the authors investigate the internationalization strategies (extent of internationalization, breadth of internalization, and home region orientation) of different types of family firms (i.e., weak family-owned, strong family-owned, and family-owned-and-managed) vs. non-family firms, considering how differences in family involvement alter the perceptions of potential gains and losses to socioemotional and financial wealth. Relying on a mixed gamble perspective and on a sample of 935 Standard \& Poor's 1500 firms from 2003-2006, their analysis shows that the nature of family involvement (i.e., family management and level of ownership) influences the perception of risk associated with potential losses of SEW from internationalization, thereby leading to diverse internationalization strategies among family firms.

Likewise, although relying on the socioemotional wealth perspective and agency theory, Ray et al. (2018) show that the heterogeneity among family firms in their ownership structure, concentration, and family involvement in management influences the internationalization strategy in terms of export and outward FDI intensity. Drawing primarily on SEW and agency theory, the authors claim that family owners and managers are not favorably disposed toward a risky internationalization strategy. However, specific contingencies, such as the presence of foreign institutional owners, help family members improve their understanding of international markets, reduce the fear of the unknown, and appreciate the benefits of internationalization. Through an empirical analysis on a longitudinal panel dataset of 303 family-owned Indian firms listed on the S\&P Bombay Stock Exchange (BSE) 500 index covering a six-year period from 2007-08 to 2012-13, this paper 
uncovers some interesting facets of how heterogeneity in ownership and management influences family firms' internationalization, especially in under-represented regions, such as Asia.

Yamanoi and Asaba (2018) investigate the influence of family ownership on a particular aspect of the internationalization process, i.e., choice of entry mode in foreign markets, distinguishing between greenfield investments vs. acquisitions, and focusing on full equity as an ownership mode. Using data on foreign subsidiaries established by 117 Japanese public firms in the electronic machinery industry between 1996 and 2007, the authors find that family ownership increases the likelihood that the parent firm engages in a greenfield investment rather than acquisition to establish a foreign subsidiary, as well as the likelihood that the parent firm pursues full ownership of a foreign subsidiary rather than partial ownership. Moreover, they contribute to existing literature by showing the moderating role of the degree of corruption in the host country, which strengthens the positive relationship between family ownership and the likelihood of engaging in a greenfield investment relative to acquisition. In doing so, this article sheds light on the influence of an important factor linked to the exo context.

Fang et al. (2018) examine how variations in the extent of family control, combined with differences in the goals of founding and later generation family owner-managers, influence their engagement in international activities (measured through the ratio of foreign sales to total sales), and how the availability of knowledge-based resources moderates these relationships. Relying on a longitudinal analysis of Standard \& Poor's 1500 manufacturing firms, the authors show that compared to non-family firms, as the ownership of family firms managed by the founding generation of a family increases, internationalization decreases, whereas the amount of family ownership of firms managed by later generation family members has the opposite effect. However, they also find that the level of knowledge-based 
resources and founding (later) generation ownership positively (negatively) influence internationalization. In doing so, this article illuminates how one important factor characterizing family involvement (i.e., extent of family control) interacts with a chrono context variable (i.e., involvement of founding or later generations) to influence internationalization outcomes.

In the only conceptual article published in this special issue, Kano and Verbecke (2018) investigate how the idiosyncratic characteristics of family firm governance cause internationalization patterns along two dimensions, i.e., location choice and operating mode. Relying on internalization theory, the authors argue, perhaps controversially, that there is no generic difference between a family and a non-family multinational enterprise's internationalization path. However, bifurcation bias, defined as the de facto differential treatment of family or heritage assets vs. non-family assets, is a family-firm specific barrier to achieving efficiency in international operations. Specifically, in the short term, the most important difference in international operations is between bifurcation-biased family multinationals and other types of multinationals. In the longer term, biased decisions will become uncompetitive in international markets and will require either eliminating bifurcation bias from their governance practices or switching to another form of governance. Thus, the important differentiator in internationalization paths is not between family and non-family firms, but between bifurcation-biased family firms and all other firms.

Stadler et al. (2018) focus on a type of inverse causality, i.e., the moderating effect of product and international diversification on the relationship between the presence of family and professional managers and economic performance measured through Return on Assets (ROA). Using a panel dataset of 262 German listed firms from 2000 to 2009, the authors show that international diversification (product diversification) negatively (positively) 
moderates the relationship between the proportion of family members in the top management team and the company's performance.

The study investigates how the degree and scope of a family firm's international activities influence the achievement of organizational goals (i.e., a certain ROA) through the effects of resources, such as the human and social capital of family and professional managers.

\section{SOME DIRECTIONS FOR FUTURE RESEARCH}

Despite the abundance of studies on family firms and their role in the global economy, major research avenues remain to be explored on the intersection between international business and family business. We start by acknowledging the need for further theoretical and empirical research that accounts for the high level of heterogeneity among family firms and disentangles the effects that variations in the forms of family involvement, behavioral propensities, governance systems, resources, and goals have on their internationalization processes and outcomes. For instance, how do the heterogeneous behavioral propensities of involved families and/or the ensuing variations in terms of their governance systems, goals, and resources shape internationalization processes? Moreover, we call for a more finegrained conceptualization of internationalization to understand how different forms of family involvement affect different aspects of internationalization processes, including, for instance, timing and speed of internationalization, scope and degree of internationalization, but also de-internationalization and divestments.

Second, there is a need to more carefully include variables in theoretical and empirical studies capturing the exo context i.e., variables linked to industry, social, political, cultural, and technological factors, and their impact on firms' internationalization processes. For instance, family firms are particularly concerned about their legitimacy and reputation and tend to behave as responsible corporate citizens that develop good relationships with local 
actors and institutions to achieve a strong level of social legitimacy. Therefore, the willingness and ability to develop strong and stable relationships with local stakeholders and institutions is a crucial factor influencing family firms' internationalization. Likewise, recent research points to the importance of more prominently taking into account the industrial sector when developing theories about firm behavior (De Massis et al., 2017), and we underline the potential of future studies employing sector-based variables to advance current understanding of the industry-specific determinants, processes, and outcomes of internationalization in family firms.

Third, we call for future research adopting a temporal perspective when studying the internationalization of family firms. As such, we urge scholars to examine the influence that factors that occur over the family and/or business' lifecycle may have on family firm internationalization. For instance, our knowledge of how intra-family succession intention (De Massis et al., 2016b) may affect the internationalization determinants and processes is still limited. Likewise, we still have little knowledge of generational effects on internationalization (e.g., comparing founder-led family firms vs. sibling partnerships vs. cousin consortiums, e.g., Gersick et al., 1997), or how situational variables, such as environmental jolts (e.g., Smith, 2016) and duration of family ownership (e.g., Zellweger et al., 2012), may affect the ability and/or willingness of family firms to internationalize their business. Overall, there is a need to understand whether and how the involved family's ability and willingness to pursue internationalization change over time under the effect of scattered events or following cumulative processes.

Fourth, our research agenda calls for more research aimed at understanding the performance implications of internationalization, and the role that governance-, resource- and goal-related characteristics of family firms have in determining internationalization outcomes. For instance, Lu et al. (2015) found that while internationalization has a positive 
impact on growth, it has a negative impact on profitability, and the governance system of the family firm positively moderates the relationship between internationalization and profitability. What are the economic and non-economic outcomes of the internationalization processes at the firm and subsidiary level? What are such outcomes at the family and business level? Moreover, further research is needed to illuminate the extent to which the idiosyncratic characteristics of a family firm change and/or interact with the internationalization process and outcomes.

Table 2 summarizes some questions for future research associated with the research directions we have outlined above.

\section{Insert Table 2 here}

In addition to these four directions for future research, we also recognize some methodological and empirical challenges at the intersection of family business and global strategy literature. In this regard, special attention should be paid to ensuring the quality of ownership data in large-scale quantitative studies. The well-documented gap between first and ultimate owners (Faccio and Lang, 2002) can be particularly acute in the case of family firms where pyramiding, preferred share issues, and other similar legal tools are common to ensure family control. Similarly, particular care should be taken to address self-selection issues generating potential endogeneity problems. Family firms tend to be concentrated in specific sectors (Demsetz and Lehn, 1985) and in specific countries (Faccio and Lang, 2002; Heugens, van Essen, and van Oosterhout, 2009), typically those with weaker corporate governance institutions. In other words, they are not randomly distributed among industries and regions, which raises potential endogeneity concerns that future empirical studies should adequately address.

In conclusion, do we need additional studies on family business and internationalization? The answer to this question is undoubtedly yes. Beyond the future research directions we 
outline in this paper, we recognize the opportunity to integrate complementary approaches to explain family firms' internationalization. Given the many contingencies that might affect internationalization in family firms, we have only started to scratch the surface of the issues that need to be investigated. Nevertheless, we will consider our efforts successful if we have encouraged other scholars to tackle some of the interesting research directions emerging from our examination of the determinants, processes, and outcomes of internationalization in family firms.

\section{REFERENCES}

Aguilera R, Crespi-Cladera R. 2012. Firm family firms: current debates of corporate governance in family firms. Journal of Family Business Strategy 3(2): 66-69.

Aldrich HE, Cliff JE. 2003. The pervasive effects of family on entrepreneurship: toward a family embeddedness perspective. Journal of Business Venturing 18: 573-596.

Alessandri et al. 2018.

Anderson RC, Reeb DM. 2003. Founding-family ownership and firm performance: evidence from the S\&P 500. Journal of Finance 58(3): 1301-28.

Anderson RC, Reeb DM. 2004. Board composition: balancing family influence in S\&P 500 firms. Administrative Science Quarterly 49(2): 209-237.

Arregle JL, Duran P, Hitt M, van Essen P. 2017. Why is family firms' internationalization unique? A meta-analysis. Entrepreneurship Theory and Practice 41(5): 801-831.

Arregle J-L, Naldi L, Nordquist M, Hitt M. 2012. Internationalization of family-controlled firms: a study of the effects of external involvement in governance. Entrepreneurship Theory and Practice 36(6): 1115-1143.

Astrachan JH, Shanker MC. 2003. Family businesses' contribution to the US economy: a closer look. Family Business Review 16(3): 211-219.

Banalieva E, Eddleston K. 2011. Home regional focus and performance of family firms: the role of family vs. non-family leaders. Journal of International Business Studies 42(8): 1060-1072.

Banalieva ER, Eddleston K, Zellweger R. 2014. When do family firms have an advantage in transitioning economies? Toward a dynamic institution-based view. Strategic Management Journal 36(9): 1358-1377.

Baumrind D. 1971. Current patterns of parental authority. Developmental Psychology Monograph 4: 1-103.

Berrone P, Cruz C, Gomez-Mejia LR. 2012. Socioemotional wealth in family firms theoretical dimensions, assessment approaches, and agenda for future research. Family Business Review. 25(3): 258-279.

Bhaumik S, Driffield N, Pal S. 2010. Does ownership structure of emerging market firms affect their outward FDI? The case of the Indian automotive and pharmaceutical sectors. Journal of International Business Studies. 41(3): 437-450. 
Bird M, and Wennberg K. 2014. Regional influences on the prevalence of family vs. nonfamily startups. Journal of Business Venturing 29(3): 421-436.

Bloom N, Van Reenen J. 2007. Measuring and explaining management practices across firms and countries. Quarterly Journal of Economics 122(4): 1351-1408.

Boellis A, Mariotti S, Minichilli A, Piscitello, L. 2016. Family involvement and firms' establishment mode choice in foreign markets. Journal of International Business Studies 47(8): 1-22.

Botero I, Cruz C, DeMassis A, Nordqvist M. 2015. Family business research in the European context. European Journal of International Management 9(2): 139-159.

Carney M. 2005. Corporate governance and competitive advantage in family-controlled firms. Entrepreneurship Theory and Practice 36(6): 1115-1143.

Carney M, Duran P, van Essen M, Shapiro D. 2017. Family firms, internationalization, and national competitiveness: does family firm prevalence matter? Journal of Family Business Strategy 8(1): 123-136.

Carr C, Bateman S. 2009. International strategy configurations of the world's top family firms. Management International Review 49(6): 733-758.

Casillas JC, Pastor F. 2015. The Top 250 Multinational Family Firms, Chair of Santander Family Business, University of Seville (Spain), retrieved from: http://www.multinationalfamilybusiness.com

Casillas JC, Moreno-Menéndez AM. 2014. Speed of the internationalization process: the role of diversity and depth in experiential learning. Journal of International Business Studies 45(1): 1-17.

Casson MC. 1999. The economics of the family firm. Scandinavian Economic History Review 47(1): 10-23.

Chang Y-C, Kao M-S, Kuo A. 2014. The influences of governance quality on equity-based entry mode choice: the strengthening role of family control. International Business Review 23(5): 1008-1020.

Cheng Q. 2014. Family firm research - a review. China Journal of Accounting Research. 7(3): 149-153.

Chrisman JJ, Chua JH, Litz RA. 2004. Comparing the agency costs of family and nonfamily firms: Conceptual issues and exploratory evidence. Entrepreneurship Theory and Practice 28(4): 335-354.

Chrisman JJ, Chua JH, Pearson AW, Barnett T. 2012. Family involvement, family influence, and family-centered non-economic goals in small firms. Entrepreneurship Theory and Practice. 36(2): 267-293.

Chrisman JJ, Fang H, Kotlar J, De Massis A. 2015. A note on family influence and the adoption of discontinuous technologies in family firms. Journal of Product Innovation Management. 32(3): 384-388.

Chua J, Chrisman J, Steier L, Rau S. 2012. Sources of heterogeneity in family firms: an introduction. Entrepreneurship Theory and Practice 36(6): 1103-1113.

Claessens S, Djankov S, Lang LH. 2000. The separation of ownership and control in East Asian corporations. Journal of Financial Economics 58(1): 81-112.

Claver E, Rienda L, Quer D. 2009. Family firm's international commitment: the influence of family-related factors. Family Business Review 22(2): 125-135. 
Combs JG, Jaskiewicz P, Shanine KK, Balkin DB. 2017. Making sense of HRM in family firms: Antecedents, moderators, and outcomes. Human Resource Management Review DOI:10.1016/j.hrmr.2017.05.001.

D'Angelo A, Majocchi A, Buck T. 2016. External managers, family ownership and the scope of SME internationalization. Journal of World Business 51(4): 534-547.

Danes SM, Lee J, Stafford K, Heck RKZ. 2008. The effects of ethnicity, families and culture on entrepreneurial experience: an extension of sustainable family business theory. Journal of Developmental Entrepreneurship 13(3): 229-268.

De Massis A, Audretsch D, Uhlaner L, Kammerlander N. 2018. Innovation with limited resources: management lessons from the German Mittelstand. Journal of Product Innovation Management 35(1), 125-146. DOI: 10.1111/jpim.12373.

De Massis A, Di Minin A, Frattini F. 2015. Family-driven innovation: resolving the paradox in family firms. California Management Review 58(1): 5-19.

De Massis A, Frattini F, Kotlar J, Messeni-Petruzzelli A, Wright M. 2016a. Innovation through tradition: lessons from innovative family businesses and directions for future research. Academy of Management Perspectives 30(1): 93-116.

De Massis A, Kotlar J, Chua JH, Chrisman JJ. 2014. Ability and willingness as sufficiency conditions for family-oriented particularistic behavior: implications for theory and empirical studies. Journal of Small Business Management 52(2): 344-364.

De Massis A, Kotlar J, Mazzola P, Minola T, Sciascia S. 2018. Conflicting selves: family owners' multiple goals and self-control agency problems in private firms. Entrepreneurship Theory \& Practice DOI: 10.1111/etap.12257.

De Massis A, Kotlar J, Wright M, Kellermanns F. 2017. Sector-based entrepreneurial capabilities and the promise of sector studies in entrepreneurship. Entrepreneurship Theory \& Practice In press. DOI: 10.1177/1042258717740548.

De Massis A, Sieger P, Chua JH, Vismara S. 2016b. Incumbents' attitude toward intrafamily succession: an investigation of its antecedents. Family Business Review 29(3): 278-30.

Demsetz H, Lehn K. 1985. The structure of corporate ownership: causes and consequences. Journal of Political Economy 93(6): 1155-1171.

Denis D, Denis D, Sarin A. 1999. Agency problems, equity ownership, and corporate diversification. Journal of Finance 52(1): 135-160.

Faccio M, Lang LHP. 2002. The ultimate ownership of Western European corporations. Journal of Financial Economics 65(3): 365-95.

Family Firm Institute 2017. Global Data Points. Retrieved from the FFI website on November 27, 2017: http://www.ffi.org/page/globaldatapoints.

Fang et al. 2018.

Fernández Z, Nieto M. 2005. Internationalization strategy of small and medium-sized family businesses: some influential factors. Family Business Review 18(1): 77-89.

Fernández Z, Nieto M. 2006. Impact of ownership on the international involvement of SMEs. Journal of international Business Studies 37(3): 340-351.

Filser M, De Massis A, Gast J, Kraus S, Niemand T. 2017. Tracing the roots of innovativeness in family SMEs: The effect of family functionality and socioemotional wealth. Journal of Product Innovation Management DOI: 10.1111/jpim.12433.

Fitzpatrick MA, Ritchie LD. 1994. Communication schemata within the family. Human Communication Research 20(3): 275-301. 
Gallo MA, Pont CG. 1996. Important factors in family business internationalization. Family Business Review 9(1): 45-59.

Galvin KM, Bylund CL, Brommel BJ. 2012. Family Communication: Cohesion and Change (8th ed). Pearson Education Inc.

Gedajlovic ER, Carney M. 2010. Markets, hierarchies, and families: toward a transaction cost theory of the family firm. Entrepreneurship Theory and Practice 34(6): 1145-1172.

Gersick KE, Davis JA, Hampton M, Lansberg MI. 1997. Generation to Generation: Life Cycles of the Family Business. Harvard Business Press, Boston.

Gomez-Mejia L, Haynes KT, Núñez-Nickel M, Jacobson KJL, Moyano-Fuentes J. 2007. Socioemotional wealth and business risks in family-controlled firms: evidence from Spanish olive oil mills. Administrative Science Quarterly 52(1): 106-137 32.

Gomez-Mejia L, Makri M, Larraza-Kintana M. 2010. Diversification decisions in familycontrolled firms. Journal of Management Studies 47(2): 223-52.

Graves C, Thomas J. 2006. Internationalization of Australian family firms: a managerial capabilities perspective. Family Business Review 19(3): 207-224.

Graves C, Thomas J. 2008. Determinants of the internationalisation pathways of family firms: an examination of family influence. Family Business Review 21(2): 151-167.

Habbershon TG, Williams ML. 1999. A resource-based framework for assessing the strategic advantages of family firms. Family Business Review 12 (1): 1-22.

Hambrick DC, Finkelstein S. 1987. Managerial discretion: a bridge between polar views of organizational outcomes. Research in Organizational Behavior 9(2): 369-406.

Hennart JF. 2014. The accidental internationalists: a theory of born globals. Entrepreneurship Theory and Practice 38(1): 117-135.

Hennart JF, Majocchi A, Forlani E. 2017. The myth of the stay-at-home family firm: how family-managed SMEs can overcome their internationalization limitations. Journal of International Business Studies DOI: 10.1057/s41267-017-0091-y.

Hernandez et al. 2018.

Heugens PP, van Essen M, van Oosterhout JH. 2009. Meta-analyzing ownership concentration and firm performance in Asia: towards a more fine-grained understanding. Asia Pacific Journal of Management 26(3): 481-512.

Jaskiewicz P, Combs J, Shanine K, Kacmar M. 2017. Introducing the family: a review of family science with implications for management research. Academy of Management Annals 11(1): 309-341.

Jaskiewicz P, Dyer WG. 2017. Addressing the elephant in the room: dis-entangling family heterogeneity to advance family business research. Family Business Review DOI: 10.1177/0894486517700469.

Jensen M, Meckling W. 1976. Theory of the firm: managerial behavior, agency costs and ownership structure. Journal of Financial Economics 3(4): 305-360.

Kano and Verbecke 2018.

Kontinen T, Ojala A. 2010. The internationalization of family business: a review of extant research. Journal of Family Business Strategy. 1(2): 97-107.

Kontinen T, Ojala A. 2012. Internationalization pathways among family-owned SMEs. International Marketing Review 29(5): 496-518.

Kotlar J, De Massis A. 2013. Goal setting in family firms: goal diversity, social interactions, and collective commitment to family-centered goals. Entrepreneurship Theory \& Practice 37(6): 1263-1288. 
Kotlar J, Signori A, De Massis A. Vismara S. 2017. Financial wealth, socioemotional wealth and IPO underpricing in family firms: a two-stage gamble model. Academy of Management Journal DOI: 10.5465/amj.2016.0256.

Kuo A, Kao MS, Chang YC, Chiu CF. 2012. The influence of international experience on entry mode choice: Difference between family and non-family firms. European Management Journal 30(3): 248-263.

Liang X, Wang L, Cui Z. 2014. Chinese private firms and internationalization: effects of family involvement in management and family ownership. Family Business Review 27(2): 126-141.

Lien Y-C, Piesse J, Strange R, Filatotchev I. 2005. The role of corporate governance in FDI decisions: evidence from Taiwan. International Business Review 14(6): 739-763.

Lin W-T. 2012. Family ownership and internationalization processes: internationalization pace, internationalization scope, and internationalization rhythm. European Management Journal 30(1): 47-56.

Lorsch JW, MacIver E. 1989. Pawns or Potentates: The Reality of America's Corporate Boards. Boston, MA: Harvard Business School Press.

Lu, J.W., Liang, X., Shan, M., Liang, X. 2015. Internationalization and performance of Chinese family firms: The moderating role of corporate governance. Management and Organization Review 11(4): 645-678 .

Majocchi A, D'Angelo A, Forlani E, Buck T. In Press. Bifurcation bias and exporting: can foreign work experience be an answer? Insights from European family SMEs. Journal of World Business.

Majocchi A, Strange R. 2012. International diversification: the impact of ownership structure, the market for corporate control ad board independence. Management International Review 52(6): 879-900.

Mederer H, Hill R. 1983. Critical transitions over the family life span. Marriage \& Family Review 6: 39-60.

Miller D, Le Breton-Miller I. 2006. Family governance and firm performance: agency, stewardship, and capabilities. Family Business Review 19(1): 73-87.

Miller D, Le Breton-Miller I, Lester R, Canella AA Jr. 2007. Are family firms really superior performers? Journal of Corporate Finance 13(5): 829-858.

Miller D, Minichilli A, Corbetta G. 2013. Is family leadership always beneficial? Strategic Management Journal 34(5): 553-571.

Morck R, Shleifer A, Vishny, RW. 1988. Management ownership and market valuation: an empirical analysis. Journal of Financial Economics 20(3): 293-315.

Muñoz-Bullon F, Sanchez-Bueno M. 2012. So family ties shape the performance consequences of diversification? Evidence from the European Union. Journal of World Business 47(3): 469-277.

Olson PD, Zuiker VS, Danes SM, Stafford K, Heck RK, Duncan KA. 2003. The impact of the family and the business on family business sustainability. Journal of Business Venturing 18(5): 639-666.

Piva E, Rossi-Lamastra C, De Massis A. 2013. Family firms and internationalization: an exploratory study on high-tech entrepreneurial ventures. Journal of International Entrepreneurship 11(2): 108-129. 
Pongelli C, Caroli MG, Cucculelli M. 2016. Family business going abroad: the effect of family ownership on foreign market entry mode decisions. Small Business Economics 47(3): 787-801.

Popenoe D. 1996. Life Without Father: Compelling New Evidence that Fatherhood and Marriage are Indispensable for the Good of Children And Society. Simon and Schuster.

Pukall TJ, Calabrò A. 2014. The internationalization of family firms: a critical review and integrative model. Family Business Review 27(2): 103-125.

Ray et al. 2018.

Reuber R. 2016. An assemblage-theoretic perspective on the internationalization of family firms. Entrepreneurship Theory \& Practice 40(6): 1269-1286.

Ritchie LD, Fitzpatrick MA. 1990. Family communication patterns measuring intrapersonal perceptions of interpersonal relationships. Communication Research 17(4): 523-544.

Rodgers RH. 1964. Toward a theory of family development. Journal of Marriage and Family 26(3): 262-270.

Sanchez-Bueno M, Usero B. 2014. How may the nature of family firms explain the decisions concerning international diversification? Journal of Business Research 67(7): 13111320 .

Sciascia S, Mazzola P, Astrachan J, Pieper T. 2012. The role of family ownership in international entrepreneurship: exploring nonlinear effects. Small Business Economics 38(1): 15-31.

Silverstein M, Bengtson VL. 1997. Intergenerational solidarity and the structure of adult child- parent relationships in American families. American Journal of Sociology 103(2): 429-460.

Simon H. 2009. Hidden Champions of the 21 st Century. Berlin: Springer.

Sirmon DG, Hitt MA. 2003. Managing resources: linking unique resources, management, and wealth creation in family firms. Entrepreneurship Theory and Practice 27(4): 339-358.

Smith C. 2016. Environmental Jolts. Understanding how family firms respond and why. Family Business Review. 29(4): 401-423.

Stadler et al. 2018.

Strange R, Filatotchev I, Buck T, Wright M. 2009. Corporate governance and international business. Management International Review 49(4): 395-407.

Tharawat Magazine. 2014. The Economic Impact of Family Business. Issue 22, May.

Verbeke A, Kano L. 2010. The transaction cost economics theory of the family firm: familybased human asset specificity and the bifurcation bias. Entrepreneurship Theory and Practice 34(6): 1173-1182.

Verbeke A, Kano L. 2012. Transaction cost economics (TCE) and the family firm. Entrepreneurship Theory and Practice 36(6): 1183-1205.

Villalonga B, Amit R. 2009. How are U.S. family firms controlled? Review of Financial Studies 22(8): 3047-3091.

Yamanoi and Asaba 2018.

Zahra SA. 2003. International expansion of US manufacturing family businesses: the effect of ownership and involvement. Journal of Business Venturing 18(4): 495-512.

Zellweger TM, Kellermanns FW, Chrisman JJ, Chua JH. 2012. Family control and family firm valuation by family CEOs: the importance of intentions for transgenerational control. Organization Science 23(3): 851-868. 


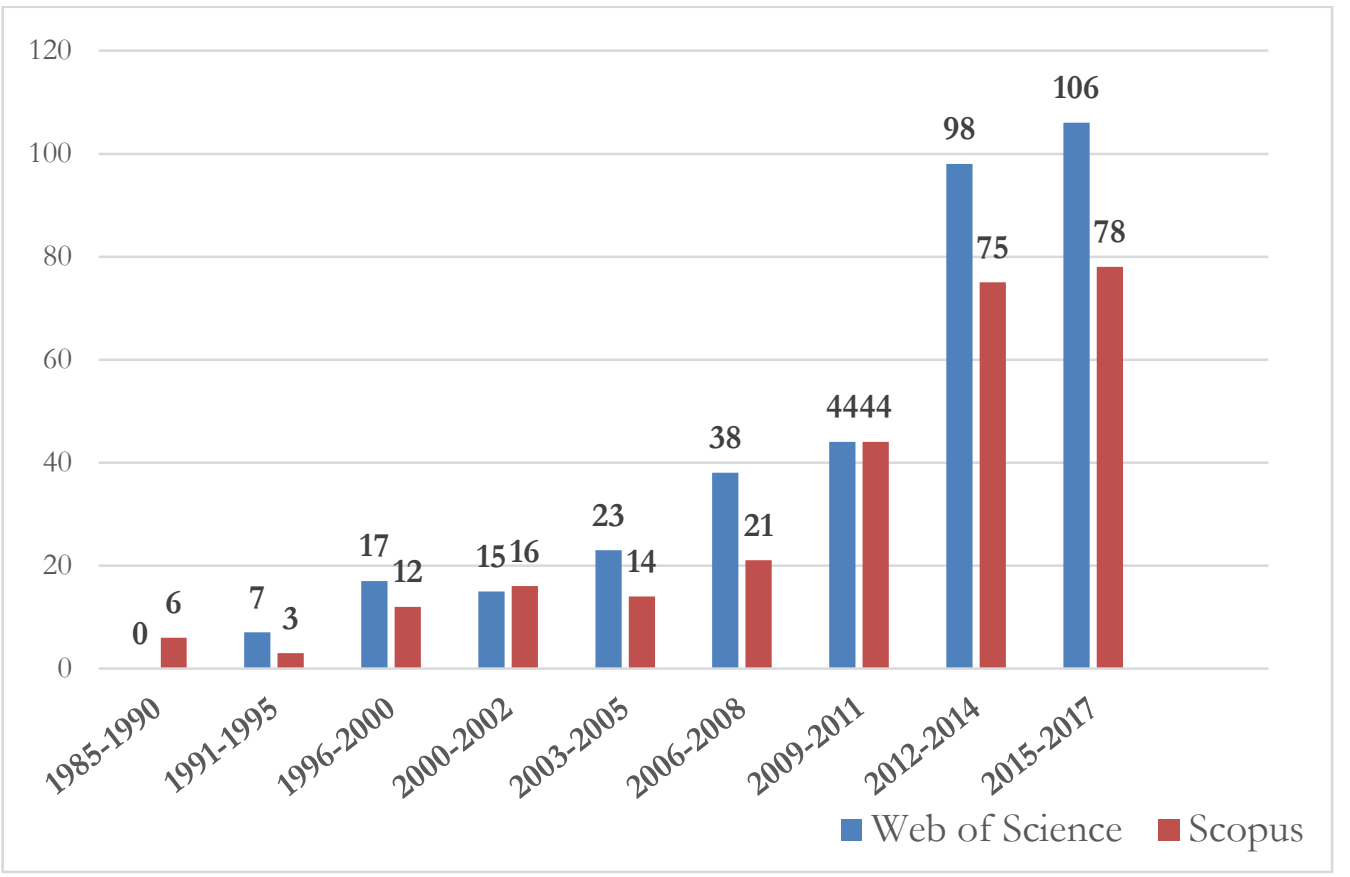

Figure 1. Number of family business articles on internationalization-related issues (1985-2017) 
Table 1. Sources of heterogeneity to understand the determinants, processes, and outcomes of internationalization in family firms

\begin{tabular}{|c|c|c|c|c|c|}
\hline & $\begin{array}{l}\text { Family } \\
\text { involvement }\end{array}$ & $\begin{array}{c}\text { Behavioral } \\
\text { propensities of } \\
\text { the involved family }\end{array}$ & $\begin{array}{l}\text { Strategic drivers of } \\
\text { family firms }\end{array}$ & $\begin{array}{l}\text { Internationalization } \\
\text { processes }\end{array}$ & $\begin{array}{l}\text { Internationalization } \\
\text { outcomes }\end{array}$ \\
\hline $\begin{array}{l}\text { Heterogeneity } \\
\text { aspects }\end{array}$ & $\begin{array}{l}\text { - Family } \\
\text { structures } \\
\text { - Family } \\
\text { functions } \\
\text { - Family } \\
\text { interactions } \\
\text { - Family events }\end{array}$ & $\begin{array}{l}\text { - Ability as discretion } \\
\text { - Ability as capability } \\
\text { - Willingness }\end{array}$ & $\begin{array}{l}\text { - Governance } \\
\text { - Resources } \\
\text { - Goals }\end{array}$ & $\begin{array}{l}\text { - Locality vs. globality } \\
\text { - Scope, modes, and location choices } \\
\text { - Timing and speed of } \\
\text { internationalization } \\
\text { - International business models }\end{array}$ & $\begin{array}{l}\text { - Economic vs. noneconomic } \\
\text { performance } \\
\text { - Firm vs. subsidiary } \\
\text { performance } \\
\text { - Family vs. business } \\
\text { performance }\end{array}$ \\
\hline \multirow{2}{*}{ Context } & \multicolumn{5}{|c|}{$\begin{array}{l}\text { Exo context: economic, social, political, legal, cultural, spatial, and technological environment } \\
\text { (e.g., industry features, network position, institutional investments; family institutions, financial markets, legal contexts) }\end{array}$} \\
\hline & \multicolumn{5}{|c|}{$\begin{array}{l}\text { Chrono context: the family and business' life courses } \\
\text { (e.g., succession, duration of family ownership, family stage, business lifecycle, business exit, mergers and acquisitions, environmental jolts) }\end{array}$} \\
\hline
\end{tabular}


Table 2. Some themes for a research agenda on internationalization in family firms

\begin{tabular}{|c|c|c|}
\hline Focus & Research Gap & Examples of Research Questions \\
\hline Family firm heterogeneity & $\begin{array}{l}\text { The impact that different } \\
\text { sources of family firm } \\
\text { heterogeneity have on } \\
\text { internationalization } \\
\text { processes }\end{array}$ & $\begin{array}{l}\text { Are internationalization processes (e.g., scope and speed of } \\
\text { internationalization) affected by family functions (such as ensuring status to } \\
\text { family members and education of young members)? } \\
\text { Is the involved family's structure (e.g., in terms of nuclear family vs. extended } \\
\text { family) responsible for different internationalization processes? } \\
\text { How do internationalization processes change under the effects of different } \\
\text { family events that take place along the family's lifecycle? } \\
\text { Do the perceptions of distance of family members explain reliance on different } \\
\text { internationalization processes in family firms? } \\
\text { Which family characteristics (in terms of structures, functions, interactions, and } \\
\text { events) are conducive to more effective and/or efficient internationalization } \\
\text { processes? } \\
\text { Are internationalization processes influenced by the characteristics of the } \\
\text { family firm's governance (such as the dispersion of family ownership, the } \\
\text { composition of the top management team, the presence of institutional } \\
\text { investors)? } \\
\text { Is the ability vs. willingness paradox in family firms a barrier to the pursuit of } \\
\text { certain internationalization processes? } \\
\text { Are family firms slower or faster at internationalizing? Does family } \\
\text { heterogeneity affect the speed of internationalization? } \\
\text { Is entry mode affected by family firm strategic drivers? How? }\end{array}$ \\
\hline Exo context & $\begin{array}{l}\text { The impact that factors } \\
\text { occurring in the external } \\
\text { environment in which the } \\
\text { family firm operates have } \\
\text { on internationalization } \\
\text { processes and outcomes }\end{array}$ & $\begin{array}{l}\text { How are internationalization processes (such as the extent of local adaptation or } \\
\text { standardization, and the degree of local embeddedness) influenced by the } \\
\text { interaction of formal and informal country institutions and the characteristics of } \\
\text { family involvement? } \\
\text { Are the resources needed to achieve superior internationalization outcomes } \\
\text { influenced by the characteristics of the industry (such as R\&D intensity) in } \\
\text { which the family firm operates? } \\
\text { How do family firms in different industrial sectors undertake different } \\
\text { internationalization processes and/or outcomes? }\end{array}$ \\
\hline Chrono context & $\begin{array}{l}\text { The impact that factors } \\
\text { occurring over time in the } \\
\text { life courses of the family } \\
\text { and the business have on } \\
\text { internationalization } \\
\text { processes and outcomes }\end{array}$ & $\begin{array}{l}\text { Are internationalization processes and outcomes influenced by generational } \\
\text { effects? } \\
\text { Do first and later generation family members differ in their willingness and } \\
\text { ability to pursue internationalization processes? } \\
\text { How do family firms adapt their internationalization processes to } \\
\text { environmental jolts? } \\
\text { How does duration of family ownership influence the willingness to pursue } \\
\text { internationalization processes and the ability to achieve superior } \\
\text { internationalization outcomes? } \\
\text { What is the effect of succession on the internationalization processes and } \\
\text { outcomes of family firms? Are there differences between internal (i.e., intra- } \\
\text { family) and external succession? } \\
\text { How do business exits and/or mergers and acquisitions affect the } \\
\text { internationalization processes of family firms? Do family firms exit faster than } \\
\text { non-family firms from foreign markets? }\end{array}$ \\
\hline
\end{tabular}




\begin{tabular}{|c|c|c|}
\hline $\begin{array}{l}\text { Internationalization } \\
\text { outcomes }\end{array}$ & $\begin{array}{l}\text { The influence that different } \\
\text { internationalization } \\
\text { outcomes have on family } \\
\text { involvement and/or the } \\
\text { behavioral propensities } \\
\text { and/or strategic drivers of a } \\
\text { family firm through } \\
\text { feedback loops }\end{array}$ & $\begin{array}{l}\text { Which family characteristics (in terms of structures, functions, interactions, and } \\
\text { events) are conducive to superior internationalization outcomes? } \\
\text { What resources and capabilities are more conducive to superior } \\
\text { internationalization outcomes (such as economic and non-economic } \\
\text { performance of subsidiaries) in family firms? } \\
\text { Is the ability vs. willingness paradox in family firms a barrier to the } \\
\text { achievement of superior outcomes? } \\
\text { How does the heterogeneity of internationalization processes in family firms } \\
\text { influence their economic and non-economic performance? } \\
\text { How do the effects on internationalization outcomes vary at the firm and } \\
\text { subsidiary level? } \\
\text { What are the performance implications of heterogeneous internationalization } \\
\text { processes on the family and business systems? } \\
\text { Do different internationalization outcomes flowing from the same } \\
\text { internationalization processes vary among different types of family firms? } \\
\text { How does the temporal evolution of the family and business systems affect } \\
\text { internationalization outcomes? } \\
\text { How do family firm internationalization outcomes influence the strategic } \\
\text { propensity of the involved family through feedback loops? } \\
\text { toops? } \\
\text { outcomes? }\end{array}$ \\
\hline
\end{tabular}

